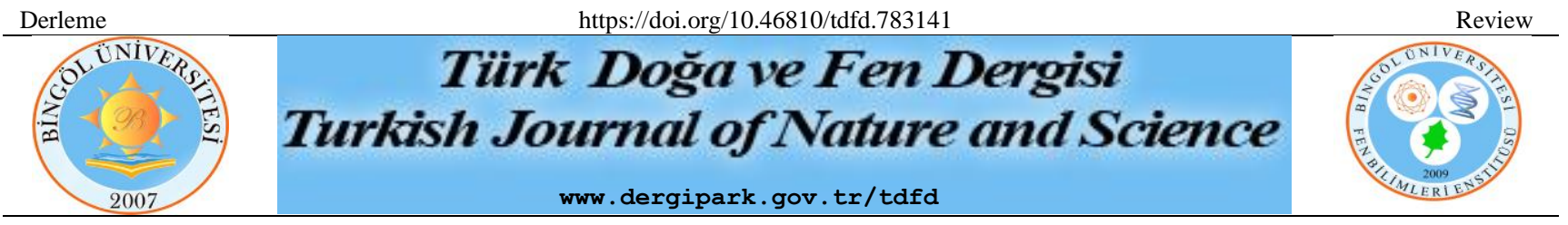

\title{
Sütçü İneklerde Neonatal Dönemde Anne ve Yavruya Gösterilecek Özen
}

\author{
Onur BAHAN ${ }^{1}$, Ahmet GÖZER ${ }^{2}$, Mustafa Kemal SARIBAY ${ }^{*}$, Emre KARSAVURANOĞLU \\ ${ }^{1}$ Yozgat Bozok Üniversitesi, Veteriner Fakültesi, Klinik Bilimler Bölümü, Veterinerlik Doğum ve Jinekolojisi \\ Anabilim Dalı, Yozgat, Türkiye \\ ${ }^{2}$ Hatay Mustafa Kemal Üniversitesi, Veteriner Fakültesi, Klinik Bilimler Bölümü, Veterinerlik Doğum ve Jinekolojisi \\ Anabilim Dalı, Hatay, Türkiye \\ Onur BAHAN ORCID No: 0000-0003-0878-6338 \\ Ahmet GÖZER ORCID No: 0000-0001-8658-5916 \\ Mustafa Kemal SARIBAY ORCID No: 0000-0002-9903-4942 \\ Emre KARSAVURANOĞLU ORCID No: 0000-0002-9771-8750 \\ *Sorumlu yazar: saribaymk@yahoo.com
}

(Alınış: 20.08.2020, Kabul: 09.03.2021, Online Yayınlanma: 25.06.2021)

\begin{abstract}
Anahtar
Kelimeler

İnek,

Doğum,

Neonatal,

Buzağı,

Yönetim

Öz: Buzağılama zamanının başarılı bir şekilde yönetilmesinin amacı, normal bir doğum süreci sonunda canlı bir buzağı elde etmek ve ineğin kuru dönemden laktasyon dönemine sorunsuz bir şekilde geçişini sağlamaktır. Bu süreçte hayvanların konfor ve rahatı için uygun padokların hazırlanması gerekmektedir. Doğumdan hemen sonra şekillenmesi olası problemler en kısa sürede belirlenmelidir. Yüksek verimli sütçü sürülerde, inekler için doğumdan hemen sonra ve erken laktasyon döneminde özel bakım ve besleme şartları sağlanmalıdır. Periparturient enfeksiyöz hastalıkların çoğunluğu buzağılamadan sonraki ilk 2 hafta içinde meydana gelmektedir. Bu nedenle yeni doğum yapan ineklerin bu süre zarfında takip edilmeleri oldukça önemlidir. Bununla birlikte buzağı ölümlerinin önemli bir kısmı doğumdan sonraki ilk 24 saat içinde gerçekleşmekte olup, toplamda ortaya çıkan ölümlerin \%75'inin ilk 7 günde olduğu ifade edilmektedir. Bu derlemede, doğum sürecinin genel yönetimi hakkında güncel bilgiler ele alınacaktır. Doğumdan sonra şekillenmesi olası problemlere yaklaşım, yeni doğum yapan ineklerin doğumdan hemen sonraki ve erken laktasyon dönemindeki beslenmesi, olası periparturient enfeksiyöz hastalıkların takibi, doğumdan hemen sonra buzağıların fiziksel muayenesi, ilk solunumun uyarımı ve göbek kordonu hijyeninin sağlanması kısaca açıklanacaktır.
\end{abstract}

\section{The Care of Dam and Calf in Dairy Cows in Neonatal Period}

Keywords
Cow,
Parturition,
Neonatal,
Calf,
Management

\begin{abstract}
The purpose of successful management of calving time is to obtain a live calf at the end of a normal calving period and to ensure smooth transition of the cow from dry period to lactating period. In this period, suitable paddocks should be prepared for the comfort and convenience of the cows. Possible problems that may occur immediately after birth should be identified as soon as possible. In high-yielding dairy herds, special care and feeding conditions should be provided for cows immediately after calving and in the early lactation period. Most of periparturient infectious diseases occur within the first 2 weeks after calving. Therefore, it is very important to follow up cows that give birth during this period. However, a significant portion of calf deaths occur within the first 24 hours after birth, and it is stated that $75 \%$ of the total deaths occur in the first 7 days. In this review, up-to-date information about the general management of the calving period will be discussed. Approach to possible problems that may occur after birth, feeding cows immediately after birth and in the early lactation period, monitoring of possible periparturient infectious diseases; physical examination, providing first respiratory stimulation and umbilical hygiene of calves immediately after birth will be briefly explained.
\end{abstract}




\section{GİRIŞ}

Buzağılama zamanının başarılı bir şekilde yönetilmesinin amac1, normal bir doğum süreci sonunda canlı bir buzağı elde etmek ve ineğin kuru dönemden laktasyon dönemine sorunsuz bir şekilde geçişini sağlamaktır [1]. Bununla birlikte yeni doğum yapan ineklerde yapılması gerekenler; hayvanların konfor ve rahatı için uygun padokların hazırlanması, uygun rasyonla besleme, bu dönemde şekillenmesi olası problemleri en kısa sürede belirleme ve tedavi protokolleri oluşturma olarak özetlenebilir [2].

Primipar inekler başta olmak üzere, ineklerde fetalmaternal boyut uyuşmazlıkları ile ilişkili güç doğumlar şekillenebilmektedir. $\mathrm{Bu}$ sebeple doğumdan sonra yumuşak doğum kanalı travma, yırtık ve kanamalar yönünden dikkatle muayene edilmeli ve gerekli tedaviler yapılmalıdır $[3,4]$. İneklerin yavru zarlarını yeme eğilimleri göz önünde tutularak atılan yavru zarları hemen uzaklaştırılmalı, atılma süreci uzuyor ise hayvan yalnız bırakılırken başı kısa bağlanmalıdır. Yeni doğum yapan inekler aşırı sıcak, soğuk ve özellikle hava cereyanlarından korunmalı ve kolay sindirilebilir yemlerle beslenmelidirler. Doğumla birlikte laktasyonun başladığı göz önünde tutularak mineral maddeler ve A-D vitaminleri yönünden zengin rasyonların hazırlanması tavsiye edilmektedir [3].

Buzağılarda yaşamlarının ilk aylarında meydana gelen ölümlerin ana nedenleri arasında bakım, besleme, barındırma koşulları ve kolostrum alımında yapılan hatalardan kaynaklı, sindirim sistemi bozuklukları ve solunum yolları hastalıkları bulunmaktadır [5,6,7]. Genç buzağılarda meydana gelen hastalıklar, doğrudan buzağı kayıplarına sebep olabileceği gibi klinik enfeksiyon sonrası hayatta kalan buză̆ıların büyümeleri ve ilerleyen dönemlerde üreme fonksiyonları ve süt verimleri üzerinde uzun vadede kalıcı etkiler oluşturabilmektedir $[8,9]$.

Sindirim ve solunum ile ilgili problemler başarılı bir buzağı yetiştiriciliğinin önündeki en büyük engellerdir. Neonatal dönemde buzağı ölümlerinin çoğu, enfeksiyöz hastalıklar (ishal, septisemi, pnömoni gibi) sonucu gerçekleşmektedir. Buna ilaveten enfeksiyöz olmayan problemler sonucu da ölümler meydana gelebilmektedir. Enfeksiyöz olmayan problemler sonucu meydana gelen ölümler doğumu takiben 2-3 gün içinde oluşmaktadır. Bu etmenler enfeksiyöz hastalıkların oluşumunda önemli risk faktörlerini oluşturmaktadır. Hipotermi ve hipoglisemi gibi fizyolojik problemler bunların en önemlileridir [10,11].

Buzağı bakımında en kritik dönem doğum sonrası ilk 24 saatlik süredir [12]. Gerek normal gerekse güç doğumlardan sonra buzağının yaşam şansını artırmak üzere; spontan solunumun kontrolüne, yavrunun beden ısısının uterus dışındaki (ekstrauterin) şartlara kolay uyum sağlayabilmesi için yardımcı olmaya (kurutmak, 1lık bir yere taşımak, kolostrumu almasını sağlamak), göbek kordonunun bakımına, anomali ve travmaların kontrolüne özen gösterilmelidir [1,3].
Deneysel koşullar altında, kolostrumun ilk verilme zamanının ve kolostrum ile besleme metodunun buzağılardaki serum immünoglobulin düzeylerini önemli ölçüde etkilediği gösterilmektedir [8]. $\mathrm{Bu}$ nedenle buzağının doğumdan hemen sonra veya en geç 4 saat sonra yeterli miktarda ve kaliteli kolostrum almas1, neonatal dönemde hastalıklara karşı pasif bağışıklığın geliştirilmesinde çok önemlidir [7].

$\mathrm{Bu}$ derlemede, doğum sürecinin genel yönetimi hakkında güncel bilgiler ele alınacaktır. Doğumdan sonra şekillenmesi olası problemlere yaklaşım, yeni doğum yapan ineklerin doğumdan hemen sonraki ve erken laktasyon dönemindeki beslenmesi, olası periparturient enfeksiyöz hastalıkların takibi, doğumdan hemen sonra buzağıların fiziksel muayenesi, ilk solunumun uyarımı ve göbek kordonu hijyeninin sağlanması kısaca açıklanacaktır.

\section{YENİ DOĞUM YAPAN İNEKLERIN BAKIM VE BESLENMESI}

Doğum ister kendiliğinden isterse yardımla gerçekleşmiş olsun, yumuşak doğum kanalındaki kanamalara, yaralanmalara, yırtılmalara ve yer değiştirmelere (prolapsus ve invaginasyonlar) dikkat edilmeli, bu durumlar ile karşılaşıldığında ise vakit geçirmeden gerekli tedaviler yapılmalıdır. Doğumun ikinci aşaması kendiliğinden ya da müdahale ile gerçekleştiği halde, şiddetli uterus sanc1ları ve annenin huzursuzluğu devam ediyorsa, uterus yavru zarlarının atılamaması (retensiyo sekundinarum) ve genital kanaldaki büyük ve derin yırtıklar yönünden dikkatlice muayene edilmelidir. Doğumdan sonra plasentanın yenmesi plasentofaji (placentophagia) olarak adlandırılır. Memelilerin büyük çoğunluğu, otçullar ve primatlar da dahil olmak üzere plasentayı tüketebilmektedir. Çoğu inek yavru zarlarını yemek istediğinden doğumdan sonra yavru zarlarının düşmesi takip edilerek ortamdan uzaklaştırılmalıdır. Yavru zarlarının yenilmesi ot yiyenler için sindirim bozukluğu meydana getirdiği gibi, atılıp atılmadığ hususunda da tereddüt oluşturarak, yanlış uygulamalara sebep olabilmektedir. İneklerde yavru zarlarının atılma süresi 12 saate kadar uzayabildiği için, atılmalarının takip edilmesi oldukça güçtür. Bu sebeple hayvanların, yavru zarları düşene kadar, atılan yavru zarlarına ulaşamayacakları şekilde kısa bağlanmaları önerilmektedir [13,14,15].

Yeni doğum yapan büyükbaş hayvanların terli olan vücutları havlu, bez ya da kuru ot yardımıyla kurulanmalı, gerekli durumlarda üstleri bir örtü ile örtülmelidir. Doğumu izleyen ilk 8-10 gün soğuktan ve sıcaktan korunmalı, 2-3 gün soğuk su içirilmemelidir. Yeni doğum yapan bütün dişileri hava cereyanından korumak gerekmektedir. Doğum yapan hayvanlara sindirilmesi kolay, besin değeri yüksek kuvvetli yemlerin, yeterli miktarda verilmesi gerekmektedir. Laktasyona başlayan hayvanlara süt verimleri de göz önünde bulundurularak, uygun yemler hazırlanmalıdır [13]. Yeni doğum yapan ineklere, doğumdan hemen sonra içerisine tuz, kepek, buğday, yulaf veya arpa unu 
ilave edilmiş en az 20 litre kadar 1lık suyun veya kalsiyum propiyonat, potasyum klorit, magnezyum sülfat, sodyum klorit, maya kültürü ve propilen glikol içeren karışımın içirilmesi oldukça faydalıdır. Bu karışım ticari olarak da bulunmaktadır [2,13]. Bu karışımların doğumdan hemen sonra 1lık su ile rumene verilmesi, doğumla birlikte yavru, yavru zarları ve sıvılarının uzaklaşması sonucu kaybedilen hacmin giderilmesini sağlamaktadır [2].

Yüksek verimli sütçü sürülerde, inekler doğumdan önce ve doğumdan sonra özel bakım ve beslemeye ihtiyaç duymaktadırlar. Buzağılamadan sonraki ilk 30 gün, inek sağlığı ve laktasyonun ekonomik başarısı için kritik bir öneme sahiptir. Yeni doğum yapan, erken laktasyon dönemindeki ineklerin süt verimlerinin artışına paralel olarak enerji ve protein gereksinimleri değişmektedir. Pik süt verimi genellikle buzağılamadan 50-60 gün sonra gerçekleşmektedir. Maksimum enerji eksikliği ise laktasyonun ilk 3 haftasında meydana gelmektedir. Bu nedenle, yeni doğum yapan ineklerin rasyonları, doğumuna 15-20 günden az kalan ineklere verilen rasyon ile en yüksek düzeyde süt veren ineklere verilen rasyon arasında bir rasyon olması gerekmektedir. Rumen fonksiyonunu korumak için iyi kaliteli $3-5 \mathrm{~kg}$ kaba yem yedirilmeli, yem tüketimindeki azalma göz önüne alınarak, rasyondaki konsantre yem miktarı artırılmalı, lifli gıdaları sindiren bakterilerin fonksiyonunu uyarmak için maya kültürü katkısı yapılmalı, rumen pH'ını sabit tutmak için bir tampon paketi eklenmeli, ketozisi en aza indirmek için niyasin (12 gr) katkısı yapılmalıdır [2,16].

Periparturient enfeksiyöz hastalıkların çoğunluğu buzağılamadan sonraki ilk 2 hafta içinde meydana gelmektedir. $\mathrm{Bu}$ süre zarfinda rektal vücut isısının izlenmesi, olası hastalıkların belirlenmesinde yardımcı olan başarılı bir yöntemdir. Dolayısıyla metritis, klinik mastitis gibi bazı enfeksiyon hastalıklarının erken teşhisi amacıyla vücut ısısının takibi günlük olarak yapılmalıdır [17]. Hayvanda aktivitenin azalması şiddetli klinik mastitis ve hipokalsemi gibi bozukluklarla ilişkili olabilir. Doğum yapan inekler, doğumdan hemen sonra kolostrum bölmesine alınmalı ve bu bölmede yaklaşık 48 saat tutulmalıdır. Daha sonra yaklaşık 10-21 gün süresince, 14 kadar inekten oluşan küçük gruplar halinde yeni doğum yapan bölmesinde tutulmalıdır. İnek, ana sürüye katılmadan önce gerekli muayeneden geçirilmeli, uterus involüsyon yönünden rektal muayene ile son kez kontrol edilmelidir [2].

\section{DOĞUM SONRASINDA YAVRUNUN BAKIMI}

Yönetim şartlarının iyi olduğu bir işletmede perinatal mortalitenin $\% 1-3$, neonatal mortalitenin $\% 3$ ve 1 aylıktan küçük buzağıların yıllık mortalitesinin \%3-5 arasında olması gerektiği ifade edilmektedir. Daha yüksek oranlar işletme yönetimi açısından problemlerin olduğunun bir göstergesi olarak kabul edilmektedir [18]. Buzağı ölümlerinin önemli bir kısmı doğumdan sonraki ilk 24 saat içinde, toplam buzağı ölümlerinin $\% 75^{\prime}$ i ise ilk 7 günde gerçekleşmektedir. Buzağı ölümlerine neden olan başlıca hastalık etmenleri güç doğum, yanlış kolostrum yönetimi, açlık, hipotermi, metabolik bozukluklar, bulașıcı hastalıklar (ishal, enterit ve pnömoni) ve travma olarak sıralanmaktadır $[19,20]$

Doğum gerçekleştikten sonra buzağıların solunum ve kalp muayeneleri, mukoza, görme ve göz reflekslerinin muayeneleri, göbek kordonu muayenesi, beden sıcaklığının ölçülmesi, derinin ve kıl yapısının durumunun tespiti dikkatli bir şekilde yapılarak, hayvanda fiziksel bir anomali olup olmadiğ 1 değerlendirilmelidir. Yavrunun canlı olup olmadığ $\breve{1}_{\mathrm{kalp}}$, nabız, pedal veya anal refleksin kontrolü ile anlaşılabilir [6,21]. İnsanlarda yenidoğan yaşama gücünün değerlendirilmesi amacıyla Apgar ve ark. [22] tarafından geliştirilen skorlama sistemi temel alınarak doğumdan hemen sonra buzağıların sağlık skoru ve hayatta kalma şansları değerlendirilebilmektedir. Kıll örtüsü görünüşü, periferal ödem, müköz membranların rengi, refleks uyarımına karşı verilen cevap, kas tonusu, kalp atımları, rektal 1s1, sternal pozisyona gelme süresi, ayağa kalkma süresi ve emme refleksinin başlama süresi gibi farklı birçok ölçütün değerlendirilerek yeni doğan buzağıların yaşama gücünün skorlanabildiği ifade edilmektedir $[21,23]$.

Doğum gerçekleşir gerçekleşmez ilk olarak yavrunun solunumu kontrol edilmelidir. Buzağılarda solunum yollarının açıklığı sağlanarak ilk solunum uyarımı için farklı birtakım yöntemler uygulanabilmektedir. İlk solunum uyarımı için buzağının başının veya kulağının üzerine soğuk su dökülmesi faydalı olmaktadır. Burun bir parmak vasitasıyla ovularak solunum refleksi uyarılabilmektedir. Buzağıları havlu ile ovalamak solunumun en önemli kası olan diyaframın sinirsel uyarımını sağlayan frenik siniri (n.phrenicus) uyarmaya yönelik bir uygulamadır [24,25,26].

Buzağının fiziksel muayenesinde akciğerlerin oskültasyonu, mükoz membranların rengi, solunumun karakteri ve frekansı belirlenmelidir. Doğumu takiben solunum başlamalı, vücuttaki artık ürünler uzaklaştırılmalı, dolaşım düzenlenerek devamı sağlanmalı, vücut 1S1Sı belli bir düzeyde tutulmalı, buzağ ayağa kalkmalı ve yürümelidir. Buzağıda ileri derecede hipoksi var ise müköz membranların siyanotik bir renk alması ile bu fark edilebilir. Hafif veya orta siddette hipoksi, mukozalarda mavimsi siyanotik bir renge sebep olmaz. Doğumdan hemen sonra sağlıklı buzağıların burun mukozası pembe iken, hipoksik olan buzağıların burun mukozası mavimsidir [11,13,27].

Sağlıklı bir buzağının nabzı, doğumu takiben kısa süre içinde dakikada 180-200 atıma ulaşır. Buzağı, kısa süre içerisinde spontan solunuma geçer. Doğduğunda annenin rektal ısısının iki derece üzerinde olan vücut 1sısı, 15-30 dakika içerisinde $39^{\circ} \mathrm{C}^{\prime} y e$ düşer. Farklı değerler buzağının dış ortama adaptasyon zorluğu çektiğini düşündürmelidir. $\mathrm{Bu}$ sebeple süreç takip edilmeli ve değerler düzelinceye kadar yavru desteklenmelidir. Doğumdan sonra buzağılar 2-3 dakika içinde sternal pozisyonda tutulmalı ve 15-30 dakika içinde ayağa kalkmaları sağlanmalıdır [11,13,19,27]. 
Doğumla birlikte göbek kordonunun kopması yavruda hipoksi meydana getirmektedir. Azalan oksijen ve artan karbondioksit konsantrasyonları veya yavrunun dış ortamla temasi solunum reflekslerini uyarmakta ve akciğer yoluyla ilk solunumun yapılmasına sebep olmaktadır. $\mathrm{Bu}$ solunum hareketi derin bir nefesle solunum başlamasına neden olur, bu da akciğer kapasitesinin artışına yol açar. Böylelikle kanda artan oksijen basıncı ve periferik vasküler rezistans, ductus arteriosus, foramen ovale ve ductus venosus'un kapanmasını başlatarak neonatal kardiyovasküler sistemin uterus dışındaki (ekstrauterin) yaşam için hazır hale gelmesini sağlamaktadır. Doğum sırasında buzağılarda respiratorik ve metabolik asidozis şekillenebilmektedir. Doğumun ve doğuma müdahalenin süresi fetal hayatta kalmayı etkilemektedir. Doğum süresinin uzaması ile birlikte asidozisin gelişmesi, merkezi sinir sisteminin baskılanmasına sebep olabilir. $\mathrm{Bu}$ da solunum reflekslerinin başlamamasına yol açabilir. Buzağı yüzeysel abdominal solunum sergiliyorsa ve refleksleri zayıf ise prognoz genellikle kötüdür [11,26,28,29].

Yeni doğan yavrunun yaşama şansı, özellikle normal solunum hareketinin kendiliğinden başlamasına bağlıdır. İlk solunumun 30 saniye içerisinde başlaması gerekmektedir. $\mathrm{Bu}$ sebeple doğumdan hemen sonra, ventilasyonu en üst düzeye çıkarmak ve ventilasyonperfüzyon eşitsizliklerini en aza indirmek için buzağı sternal yatış pozisyonuna getirilmelidir. İlk dikkat edilecek husus açık bir hava yolu oluşturarak yavrunun solunumunu sağlamaktır. $\mathrm{Bu}$ sebeple buzağının üst solunum yollarının (ağız ve burun) sıvılardan veya herhangi bir fiziksel tıkanıklıktan (elle veya vakum yoluyla) arındırılmalı ve dil ileriye doğru çekilmelidir. Akciğerlerin drenajı yapılmak isteniyor ise buzağının arka ayaklarından tutularak ters çevrilmesi ancak kısa süreli olarak yapılabilir. Buzağılar asla uzun süre arka ayaklar tarafından asılmamalıdır. Bu yöntem yerçekimi yardımıyla solunum yollarından sıvıların çıkarılmasını sağlamak için yıllar boyunca uygulanmıştır. $\mathrm{Bu}$ iş 10-20 saniye süreyle, 3-5 defa tekrarlandığı takdirde, üst solunum yoluna kaçan yavru sıvılarının hepsi boşaltılabilir. $\mathrm{Bu}$ işlemin uzun süreli ve kuvvetli yapılması akciğerlerin drenajına değil, rumendeki sıvıların geri gelmesine neden olur. Hatta bu uygulama, iç organların akciğerler üzerine basınç oluşturmasına sebep olduğundan akciğerlerin genişlemesi kısıtlanabilir. $\mathrm{Bu}$ durumda en iyi yol solunum yollarındaki mukusun vakumla alınmasıdır [11,13,26,27]. Burada dikkat edilmesi gereken en önemli nokta, neonatal buzağılarda hassas olan mukoza ve dokulara zarar vermemek için aşırı basınç ve vakumdan kaçınmaktır. Buzağılarda 5,59,5 mm'lik endotrakeal tüpler kullanılabilir. Buzağıya oksijen verilirken ilk birkaç soluk yüksek basınçta verilir. Çok yüksek basınç alveoler epitelyuma zarar verebilir. Oksijen akış1 150-200 L/dakika, basınç ise 50 PSI olmalıdır. Buzağının solunumu normale döndüğünde tüp çıkartılmalıdır [11].

Diğer bir uygulama ise suni solunumdur. Bunun için buzağı yan yatırılarak baş ve boyun ileri doğru uzatılır. Yavrunun burun deliklerinin birisinden ağıla akciğerlere hava üflenerek akciğerler şişirilir ve ardından göğüs kafesi üzerine bastırılarak boşaltılır. Bu işlemler birbiri ardından, düzenli olarak 10-15 dakika devam ettirildiği takdirde, solunum hareketleri başlayabilir. $\mathrm{Bu}$ işlem ardı sıra devam ettirildiğinde bir süre sonra buzağıda solunum hareketleri başlayabilir. Suni solunumun, akciğerlere kısa zamanda hava gönderilmesi, kalbe mesaj yapma ve dolaşımı uyarma gibi faydaları da vardır. Bu da yeterli değil ise buzağı yan yatırılır. Bir yardımcı buzağının ağzını açık tutup dilini dışarı çekerek rahat nefes almasına yardımcı olurken, bir diğer kişi de üst kol ve kostaların gerisinden yavruyu tutarak buzağıyı yerle teması kesilinceye kadar kaldırır. Bu, akciğerlerin genişlemesine yardımcı olur. Buzağı bırakılarak göğüs kafesine sıkıca basınç uygulanır. $\mathrm{Bu}$ işlem beş saniye aralıklarla düzenli solunum başlayıncaya kadar devam ettirilir. Göğüs kafesi üzerine vurma ve bastırma hareketleri sırasında aşırıya kaçılmaması gerekir. Aksi takdirde kaburgalar kırılabilir veya akciğerler zarar görebilir. Serinletme de etkili bir uyarıcı olduğundan, yavrunun vücuduna hafif soğuk su serpilmesi veya başa bir miktar soğuk su dökülmesi, solunum hareketlerini uyarır [13,19,27]. Trakeanın hafifçe sıkılması da öksürüğü de beraberinde getirebilir, buzağının öksürmesi solunum yollarının açılmasına yardımcı olan bir reflekstir [19].

Solunum merkezini uyarmak üzere parenteral olarak Lobelin (6-20 mg iv, 20-50 mg sc), Kafein (1-2 gr sc), Pikrotoksin (\%0.1'lik, 1-3 mg iv), Doxapram hidroklorit (\%1'lik, $5 \mathrm{ml})$, Pentazol-Cardiazol-Leptazol (\%10'luk 0,5-2 ml) verilebilir. Doxapram $\mathrm{HCl}$ periferal kemoreseptörleri ve beyindeki medüller reseptorik merkezi uyarır. Bu preparat geniş güvenlik toleransına sahiptir ve güvenilir bir şekilde solunum uyarımı için kullanılır. Doxapram HCL ile birlikte oksijen desteği de uygulanabilir. Yukarıda anlatılan işlemlerin ve tedavilerin uygulanmasıyla, yavru genellikle birkaç derin nefes alır ve her nefes bir sonrası için uyarı yerine geçer ki iki, üç dakika içinde normal solunum başlamazsa, nabız ve kalp atımları iyi olsa bile, yavrunun yaşama şansı azdır. Asfeksinin uzun sürmesi halinde, onarılamayacak ölçüde beyin hasarı oluşabilir, bu da tedavinin başarı şansını düşürür. Ayrıca uzun süren hipoksilerde, pH'ı düzeltmek amaciyla buzağıya 200$250 \mathrm{ml} \% 4$ sodyum bikarbonat eriyiği damar içine verilebilir $[11,13,27]$.

Kalp ritminde sorun olan derin bradikardik buzağılarda ise kalbi desteklemek amacıyla veya kalp durmalarına karş1 \%0,1'lik epinefrin 0,1-0,2 ml kg-1 dozunda intramusküler, intravenöz, intrakardiak veya intratrakeal, atropin ise $0,01-0,03 \mathrm{ml} \mathrm{kg}^{-1}$ dozunda intravenöz yolla verilir. $\mathrm{Bu}$ hızlı bir taşikardi sağlamaktadır. Yine de buzağı entübe edilmeli ve ventilasyonu desteklenmelidir. Genel olarak kalp ritmi olmadan doğan hayvanlarda ise kardiyak resüsitasyon yapılmamaktadır. Böyle bir durumda başarılı bir resüsitasyon olasılığı düşüktür $[26,27]$.

Nabız dakikada 60'ın altında ise, adrenalin $0,02 \mathrm{mg} \mathrm{kg}^{-1}$ dozunda intravenöz veya intratrakeal uygulanabilir. Acil durumda trakea içi lidokain veya atropin uygulanabilir. 
İntratrakeal verilen ilaçlar biraz sulandırılıp mümkün olduğunca trakeobronşiyal bölgenin distaline ulaştırılmaya çalışılır [11]. Yeni doğan buzağılar uterus içi (intrauterin) ortamdan uterus dişı (ekstrauterin) ortama geçerken çevre sıcaklığındaki radikal değişimlere maruz kalır. Buzağı doğduğunda islak olduğundan buharlaşma ile 1sı kaybı fazla olur. Bu nedenle yavrunun doğduğu ortam soğuk ise yavru derhal sıcak bir ortama alınarak hemen kurutulmalıdır [11]. Buzağılar, özellikle ilk dört saat içinde hipotermiye karşı duyarlıdır. Yeni doğan bir buzağının hipotermide olup olmadığı ağız içi sıcaklığın değerlendirilmesiyle anlaşılabilir. Ağız içinin soğuk olması hipoterminin bir göstergesi olabilir. Ayrıca, sağlıklı olan bir buzağıda emme refleksi bulunur. Ağız içi sıcak değilse ve emme refleksi yoksa buzağ 1 kısa süre içerisinde sıcak bir ortama alınmalıdır. Çevre koşullarının iyi olmadığı yerlerde ve soğuk mevsimlerde yavru daha korunaklı alanlara alınarak bez, havlu, kuru ot gibi materyallerle kurutulmalıdır. Böylece hem sirkülasyona yardımcı olunur hem de kuru, dikleşmiş tüyler arasındaki kuru hava ile buzağı sanki üzerine battaniye örtülmüş gibi korunur. $\mathrm{Bu}$ işlem için saç kurutma makinesi de kullanılabilir. Yavru kurutulduktan sonra üzerine battaniye veya benzeri bir örtü konulur, bulunduğu alanlarda 1sitıcılar kullanılabilir [6,27]. Annesine ve çevresine ilgisiz, durgun ve emme problemi olan buzağılara, taylarda yenidoğan uyumsuzluğu sendromunda klinik etkinliğe sahip olduğu gösterilen toraks sıkma tekniğinin uygulanmasının yararlı olabileceği bildirilmektedir [30]. Ayrıca doğumdan hemen sonra buzağılara uygulanan tek doz ketoprofenin doğum sonrası ilk birkaç gün buzağıların refahını önemli düzeyde artırdığı bildirilmektedir [31,32].

Genellikle solunumun düzenlenmesi, kolostrum alımının sağlanması, vücut 1sısının düzenlenmesi ve yavrunun ayağa kaldırılarak hareket ettirilmesi gibi destekleyici uygulamalar asidozis problemin giderilmesi için yeterlidir. Eğer bu uygulamalarla asidozis düzeltilemezse, $250-500 \mathrm{ml} \% 4,2^{\prime}$ lik sodyum bikarbonat intravenöz yolla verilir $[19,27]$.

Doğumu takiben kontamine ortamlar buzağıda ishal, solunum yolu enfeksiyonu veya septisemiye sebep olabilecek viral, bakteriyel veya protozoal etkenleri içerebilir. $\mathrm{Bu}$ etkenler çevrede uzun süre yaşayabildiği ve bulaşmanın enfekte dışkı ile temas veya dışkı ile kontamine edilmiş su veya gıdaların alınması şeklinde olduğu için, buzağının ayrı bir bölmeye alınmasında fayda vardır. Yenidoğan bölmesinin kuru, 1lık, havadar, cereyansız olması ve diğer hayvanların bulunduğu bölmeler ile direk teması olmaması gerekir. Her bir buzağı için ayrı biberon veya kaplar kullanılmalı, temizlik ve dezenfeksiyon düzenli olarak yapılmalıdır. Eller, kıyafetler ve çizmeler düzenli olarak yıkanıp dezenfekte edilerek hastalık etkenlerinin taşınması önlenmelidir [27].

Göbek kordonu doğum sırasında çoğunlukla kendiliğinden kopmaktadır. Aksi bir durumda hayvan sahibi ya da Veteriner Hekim tarafindan kesilmektedir. Göbek kordonu oluşumlarında umbilikal arter ve urakus, abdomen içine geri çekilmektedir. Umbilikal açıklık, düz kasların kontraksiyonu ve bağ doku üremesi ile 5-10 gün içinde kapanmaktadır. Umbilikal ven ve amniyotik membranın kalıntıları vücudun dışında kalır. 3-4 günde kuruyarak incelir, 5-10 gün içinde yerini yarı sikatrize olmuş bir yaraya bırakır ve 10-15 gün sonra düsser. Skar dokusu 5-10 gün içerisinde oluşurken, göbek sikatriksinin tamamlanması ortalama 2-3 hafta içinde gerçekleşmektedir $[33,34]$.

Göbek kordonu dip kısmından kopmamıs ise abdomene en yakın kısmından başlanarak aşağıya doğru parmaklarla sıvazlanmalı ve içerisindeki kanlı sıvı boşaltılmalıdır. Enfeksiyonu önlemek amacıyla en kısa sürede hafif bir antiseptik solüsyona daldırılmalıdır. Abdomene 4-5 cm uzaklıktan antiseptiğe batırılmış bir iple bağlanmalı ve bağlanan noktanın 3-4 $\mathrm{cm}$ altından temiz bir makasla kesilmelidir. $\mathrm{Bu}$ işlem doğumdan sonra yarım saat içinde yapılmalı, 12 saat arayla iki kere tekrar edilmeli ve 24 saat sonra en az bir kere daha yapılmalıdır. Göbek kordonu hafif antiseptiklerle temizlenmelidir. İrritan antiseptikler göbek bağ 1 ve etrafindaki yapının irritasyonuna ve yangılanmasına sebep olur. Antiseptik olarak en çok \%7'lik iyot çözeltisi kullanılmaktadır. Bölgeye uygulanan iyot çözeltisi göbek kordonunu kurutur ve bakterilerin göbek kordonundan girișini engeller. Bazı çalışmalarda göbek kordonunun bakımı için klorheksidin esaslı dezenfektanlar da önerilmektedir. Ayrıca, alkol de kordonun hızlı bir şekilde kurumasını sağlar. Bu yüzden mumifikasyonu hızlandırmak için tercih edilebilir. İlerleyen günlerde sprey şeklindeki antiseptik ve antibiyotikler de kullanılabilir. Antisepsinin sağlanmasından sonra, göbek kordonunun kuru ve temiz tutulması da göbek sağlığının devamını sağlamanın en iyi yoludur [6,34].

\section{KAYNAKLAR}

[1] Mee JF. Managing the dairy cow at calving time. Vet Clin North Am Food Anim Pract. 2004;20:52146. https://doi.org/10.1016/j.cvfa.2004.06.001.

[2] Öcal H, Rişvanlı A, Kalkan C, Doğan H. Süt ineklerinde peripartum dönemde anne ve yavrunun bakımı. Türkiye Klinikleri J Vet Sci Obstet Gynecol-Special Topics. 2015;1(1):42-60.

[3] Alaçam E. İnekte döl verimi ve kontrolü. In: Alaçam E, Şahal M, editors. Sı̆̆ır Hastalıkları. Ankara: Medisan Yayınları; 1997. p. 325-88.

[4] Lombard JE, Garry FB, Tomlinson SM, Garber LP. Impacts of dystocia on health and survival of dairy calves. J Dairy Sci. 2007;90:1751-60. https://doi.org/10.3168/jds.2006-295.

[5] Cobo-abreu R, Martin SW, Willoughby RA, Stone JB. The association between disease, production and culling in a university dairy herd. Can Vet J. 1979;20:191-5.

[6] Lorenz I, Mee JF, Earley B, More SJ. Calf health from birth to weaning. General aspects of disease prevention. Irish Vet J. 2011;64(10):1-8.

[7] Bolacalı M, Küçük M. Buzağı Kayıplarında İşletme Hatalarının Rolü. Buzağı Hastalıkları Sempozyumu Kitabı. Van: 2017. p. 18-21.

[8] Waltner-Toews D, Martin SW, Meek AH. Dairy calf management, morbidity and mortality in 
Ontario Holstein herds. III. Association of management with morbidity. Prev Vet Med. 1986;4:137-58. 5877(86)90019-X

[9] Donovan GA, Dohoo IR, Montgomery DM, Bennett FL. Calf and disease factors affecting growth in female Holstein calves in Florida, USA. Prev Vet Med. 1998;33:1-10.

[10] Roy JHB. Factors affecting susceptibility of calves to disease. J Dairy Sci. 1980;63:650-64.

[11] Kaya A. Buzağılarda Enzootik Pnömoni ve Neonatal asfeksi. Buzağı Hastalıkları Sempozyumu Kitab1. Van: 2017. p. 30-52.

[12] Gundelach Y, Essmeyer K, Teltscher MK, Hoedemaker M. Risk factors for perinatal mortality in dairy cattle: cow and foetal factors, calving process. Theriogenology. 2009;71:901-9.

[13] Deveci H. Gebelik ve doğuma bağlı olarak ana ile yavrunun bakım ve beslenmesi. In: Alaçam E, editor. Evcil Hayvanlarda Reprodüksiyon, Sun'i Tohumlama, Doğum ve İnfertilite. Ankara:Medisan Yayınevi; 1994. p. 183-91.

[14] Young SM, Benyshek DC. In search of human placentophagy: A cross-cultural survey of human placenta consumption, disposal practices, and cultural beliefs. Ecology of Food and Nutrition. 2010;49:467-84.

[15] Cremers GE, Low KG. Attitudes Toward Placentophagy: A Brief Report. Health Care Women Int. 2014;35:113-9. https://doi.org/10.1080/07399332.2013.798325.

[16] Hutjens MF. Practical approaches to feeding the high producing cow. Anim Feed Sci Technol. 1996;59:199-206. https://doi.org/10.1016/03778401(95)00900-0.

[17] Smith BI, Risco CA. Management of periparturient disorders in dairy cattle. Vet Clin North Am Food Anim Pract. 2005;21(2):503-21.

[18] Correa MT, Curtis CR, Erb HN, White ME. Effect of calf hood morbidity on age at first calving in Newyork Holstein herds. Prev Vet Med. 1988;6:253-262.

[19] Mee JF. Newborn dairy calf management. Vet Clin N Am Food A. 2008;24(1):1-17.

[20] Koyuncu M, Karaca M. Buzağılarda Yaşama Gücünün Anahtarı "Kolostrum". J Anim Prod. 2018;59(1):67-78.

[21] Murray CF, Leslie KE. Newborn calf vitality: Risk factors, characteristics, assessment, resulting outcomes and strategies for improvement. Vet $\mathbf{J}$. 2013;198:322-8.

[22] Apgar V, Holaday DA, James LS, Weisbrot IM, Berrien C. Evaluation of the newborn infant-second report. Journal of the American Medical Association. 1958;168(15):1985-1988.

[23] Mee JF. Managing the calf at calving time. American Association of Bovine Practitioners Proceedings of the Annual Conference, 2008. p. 4653.

[24] Brunson DB. Ventilatory support of the newborn calf. Compendium on Continuing Education for the Practicing Veterinarian. 1981;3:47-52.
[25] DeKruif A, Benedictus G. Perinatal mortality and the birth of weak calves. Tijdschr Diergeneeskd. 1993;118:684-8.

[26] Nagy DW. Resuscitation and Critical Care of Neonatal Calves. Vet Clin North Am Food Anim Pract. 2009;25:1-11. https://doi.org/10.1016/j.cvfa.2008.10.008.

[27] Ekici H, Güngör Ö. Perinatal dönemde anne ve yavruya gösterilecek özen. In: Semacan A, Kaymaz M, Fındık M, Rişvanlı A, Köker A, editors. Çiftlik Hayvanlarında Doğum ve Jinekoloji. 3rd ed. Malatya: Medipres Yayıncılık; 2019. p. 237-49.

[28] Detweiler DK, Riedesel DH. Regional and fetal circulations. In: Swenson MJ, Reece WO, editors. Dukes' physiology of domestic animals. 11th edition. Ithaca (NY): Cornell University Press; 1993. p. 227.

[29] Szenci O. Role of acid-base disturbance in perinatal mortality of calves: a review. Vet Bull. 2003;73:714.

[30] Stilwell G, Mellor DJ, Holdsworth SE. Potential benefit of a thoracic squeeze technique in two newborn calves delivered by caesarean section. New Zealand Veterinary Journal. 2020;68(1):6568.

[31] Laven R, Chambers P, Stafford K. Using nonsteroidal anti-inflammatory drugs around calving: Maximizing comfort, productivity and fertility. The Veterinary Journal. 2012;192(1):8-12.

[32] Gladden N, Ellis K, Martin J, Viora L, McKeegan D. A single dose of ketoprofen in the immediate postpartum period has the potential to improve dairy calf welfare in the first $48 \mathrm{~h}$ of life. Applied Animal Behaviour Science. 2019;212:19-29.

[33] Samsar E, Akın F. Özel Cerrahi. Malatya: Medipres Matbaacilık; 2002.

[34] Gönenci R. Buzağılarda Göbek Kordonu Bakımı ve Hastalıkları. Buzağı Hastalıkları Sempozyumu Kitab1. Van: 2017. p. 88-98. 